\title{
Law and the Demoralisation of Medicine
}

\author{
Jonathan Montgomery,
}

This is the peer reviewed version of the following article: 'Law and the Demoralisation of Medicine' (2006) 26(2) Legal Studies 185-210, which has been published in final form at DOI: 10.1111/j.1748-121X.2006.00004.x. This article may be used for non-commercial purposes in accordance With Wiley Terms and Conditions for self-archiving.

\begin{abstract}
In his Dimbleby Lecture in December 2002, the Archbishop of Canterbury examined the effect of the emergence of the market state on the legitimacy of government activity in areas of morality. He suggested that while this is becoming limited, the continuing need to provide a moral context for social life provided an opportunity for religious communities to play a crucial role. This piece suggests that the increasing significance of market concepts in health care law poses a similar challenge to the moral basis of medical practice, threatening to drive moral argument outside of the scope of the discipline with the consequent effect of undermining the values that drive good health care. Thus the de-moralisation of medicine is also demoralising for those within the health professions. To counteract this tendency, a strong sense of a common moral community needs to be maintained amongst those engaged with the discipline of health care law.
\end{abstract}

This paper also examines the role of law in this area. Traditionally, legal scholars have attacked the reluctance of legislators and the judiciary to wrestle from the grip of doctors the authority to determine ethical issues. The dominant view has been that this was a failure to recognise the fact that society has a stake in these matters and that legal non-intervention was an abdication of responsibility that undermines the rule of law. However, the integration of medical and moral decision-making into a collaborative enterprise can also be seen as a more effective defence against the forces of demoralisation than the separation that the orthodox approach implies. If this is correct, then a key task for health care lawyers, as yet undeveloped, is to consider how to establish a legitimate common moral community, and what role the law might have to play in that process.

\section{Introduction}

An inaugural lecture is an opportunity to take stock of one's subject, to ask how it has reached the state that it is in and to consider where it might be going. ${ }^{1}$ It is also a chance to give recognition to the thinkers and influences that have played a role in paving the path that is being trod.

My inspiration for the specific form of this lecture has come from the Dimbleby Lecture delivered by Rowan Williams, the Archbishop of Canterbury in December 2002. ${ }^{2}$ He took as a theme the argument of the American strategist, historian and legal academic Philip Bobbitt. In a monumental book, The Shield of Achilles, ${ }^{3}$ Bobbitt argued that the world of the nation-state was ending and that the new context for the exercise of authority, including legal authority, was the market state. In this new world order, the legitimacy of governments over moral and social issues was severely diminished and the practical reach of their power substantially limited. On Bobbitt's account, the market state is legitimated by its ability to increase choice and

\footnotetext{
${ }^{1}$ This paper is a revised version of an inaugural lecture delivered in Southampton on 12 November 2003. I am grateful to many friends and colleagues for their comments before and since. Amongst the most significant commentators on this particular paper have been Margot Brazier, Jose Miola, Elsa Montgomery, Derek Morgan and Jenny Steele. I take full responsibility for the weaknesses that remain.

${ }^{2}$ The text of the speech can be downloaded from www.archbishopofcanterbury.org.

${ }^{3}$ P Bobbitt, The Shield of Achilles (London, Penguin 2002).
} 
opportunity rather than any substantive values. As a result, it has lost the right to enforce any particular morality. His examples are wide ranging, but include health care issues such as the loss of the power to restrict access to contraception and abortion. $^{4}$

Rowan Williams noted that in such a world, government and culture - the ability to locate the choices we make within a framework of values - drift apart. Elsewhere, he has pointed out that making mature choices involves closing down some possibilities as well as opening up others. Pursuing choice alone, as an intrinsic rather than an instrumental good, undermines our opportunities to build up a consistent pattern of decision making. In fact, it infantilises us by robbing us of the chance to build a framework of meaning, of which morality is an important part. Choice in this sense is actually in conflict with autonomy, if that is understood as living according to one's own system of values. It undermines the creation of a value system by presenting choices over time as unconnected with each other and encouraging arbitrariness rather than consistency. ${ }^{5}$

In the Dimbleby Lecture, Williams argued for the place of religion in sustaining the possibility of morality in this new world. If governments are losing legitimacy in the enforcement of morality, he suggested, this made it even more important that religions embraced the responsibility for giving life 'meaning'. He summarised the issue in these terms:

In the pre-modern period, religion sanctioned the social order; in the modern period it was a potential rival to be pushed to the edges, a natural reaction. But are we at the point where, as the 'public sphere' becomes more value-free, the very survival of the idea of a public sphere, a realm of political argument about vision and education, is going to demand that we take religion a good deal more seriously?

I want to ask similar questions about the role of law in the world of health care. I will suggest that the discipline of health care law is at risk of being transformed. Moving from a discipline in which the moral values of medical ethics (and those of the nonmedical health professions) are a central concern, to one in which they are being supplanted by an amoral commitment to choice and consumerism. ${ }^{6}$ In other words, that the morality is being taken out of medicine by legal activity. I would not claim that law is the only pressure pushing in this direction. Both Labour and Conservative rhetoric on their plans for the National Health Service place 'choice' at the centre, as the main value to be pursued. ${ }^{7}$ However, health care law has the potential to be applied either to resist this drift into choice for its own sake, unrooted in more fundamental values, or to promote it and we should examine its place carefully.

The issues can be traced in the context of the doctrine of informed consent, one of the fundamental building blocks of both health care ethics and health care law. ${ }^{8}$ In

\footnotetext{
${ }^{4}$ See e.g. p 230 for his analysis of the current position and pp 735-6 for a vision of the future.

${ }^{5}$ R. Williams, Lost Icons (London, T \& T Clark 2000), esp. ch 1.

${ }^{6}$ I raised concerns of a similar nature about the emergence of a rights model in 'Patients first: the role of rights' in K. Fulford, S. Ersser \& T. Hope (eds) Essential Practice in Patient-Centred Care (Oxford, Blackwell Science 1996).

${ }^{7}$ The NHS Improvement Plan : Putting people at the heart of public services (London: Department of Health 2004), Setting Patients Free (London: Conservative Policy Unit 2003)

${ }^{8}$ Although strictly the full doctrine of informed consent probably remains unrecognised in English law it is dominant in the work of commentators. Even with the ambiguous reference to surgery without
} 
traditional terms, commentators have seen that doctrine as a means for promoting the autonomy of patients - their ability to take control of their lives and to shape them as they wish. ${ }^{9}$ The choices they make are one of the ways in which they shape their own life stories. Ensuring that patients receive good quality information is part of the process of enabling them to exercise such autonomy. On this account, autonomy is a positive value reflecting the sort of people we believe fully reflect our human potential. ${ }^{10}$ Informed consent in legal terms, however, can be seen as concerned as much with the constraint of power than directly with the value of autonomy itself. ${ }^{11}$ One of the threats to autonomy is external control. Requiring disclosure of information about treatment options is a mechanism to reduce the power exercised by health professionals over their patients. If patients are informed of the facts and able to exercise choice they are less vulnerable to professional control - the law ensures that it is for patients to choose what happens, not doctors. ${ }^{12}$ This is a negative justification for informed consent based on its role in limiting undesirable paternalism, but it is expected to promote the positive value of autonomy by creating the circumstances in which it can be exercised. The legal doctrine of informed consent is thus not identical to the ethical notion of autonomy, but it is justified as promoting it. $^{13}$

In the hands of some types of lawyer, however, the doctrine can take a rather different form. A particularly illuminating example of this can be seen in the Data Protection Act 1998. One area of concern arises in relation to the transfer of personal data abroad, to countries where data protection laws are less strict (such as the USA). The Data Protection Act recognises this by requiring a data controller, say a health researcher, who will be transferring information in this way to do one of two things. Either they must take steps to ensure that adequate protections are in place, such as by placing contractual limitations on the use and retention of data, or they must inform the subjects that their data will be going abroad. ${ }^{14}$

Informed consent theory would imply that the second alternative was a means of promoting autonomy - patients make their choices on the basis of explicit information and are thus able to make the choices they want unbiased by poor understanding.

informed consent being 'unlawful' in Chester $v$ Asfar [2004] UKHL 41, para 14, it seems clear that this case, the most pro-informed consent decision yet delivered, saw the relevant legal doctrine as negligence to enforce a 'duty to warn' rather than trespass where the validity of consent is the key issue (see e.g. para 60).

${ }^{9}$ See P. Alderson \& J. Montgomery, Health Care Choices: Making decisions with children (London, Institute for Public Policy Research 1996) 18-20 for a discussion of the value of autonomy in the construction of health care law.

${ }^{10}$ Consider, for example J.S.Mill's account of the importance of liberty in On Liberty (London, Dent).

${ }^{11}$ See e.g. I. Kennedy, 'The doctor-patient relationship' in P. Byrne (ed) Rights ands Wrongs in

Medicine (Oxford: Oxford University Press 1986) 7-21, esp. 12-15. Although see also the reference to autonomy and dignity as foundations in Chester v Asfar [2004] UKHL 41, per Lord Steyn at paras 18, 24.

${ }^{12}$ This, rather than 'autonomy and dignity', is the principal rationale given for the legal duty to warn patients of risks by the judges in Chester $v$ Asfar [2004] UKHL 41, see Lord Bingham (para 5), Lord Steyn (para 14 although see also para 18 as noted in the previous footnote), Lord Hope (para 86), Lord Walker (para 92). Lord Hoffman suggested that the purpose was to provide an opportunity to avoid or reduce risk, a rationale related to avoidance of harm rather than either autonomy or choice.

${ }^{13}$ See T.L. Beauchamp \& J.F. Childress, Principles of Biomedical Ethics (New York: Oxford University Press $5^{\text {th }}$ ed 2001) 77-79 for a discussion of the difference between institutional practices for gaining consent and the idea of informed consent as the exercise of autonomy.

${ }^{14}$ Data Protection Act 1998, Sch 1, Pt II, para. 13; Sch 4 para. 1; 8 th Data Protection Principle. 
However, this promotes autonomy only in a very unsatisfactory sense. For drug companies, informed consent to the transfer of information is by far the preferable route. It absolves them of any requirement to protect the privacy of research participants. Participants know what is happening, the argument goes, so the drug companies have met their legal responsibilities. The participants' ability to control what is happening to their data may be feeble, but they have been informed and can therefore exercise a choice. Their choice is, however, strictly limited. They can decline to participate in the trial but if they choose to take part they have no means to control what happens to the data when transferred abroad. Further, an apparent increase in informed consent has actually served to reduce the obligations of researchers to protect the interests of participants. Promoting participants' ability to shape their lives would be more enhanced by the researchers maintaining the responsibility for protecting privacy. The law has substituted a formal requirement of openness for a substantive one of protection. Perhaps more tellingly, the people protected by informed consent are the researchers and drug companies not the research participants. The legal doctrine of informed consent has actually undermined autonomy as it has reduced the force of the moral obligation on researchers to protect the ability of participants to shape their own lives. The law permits researchers to give information and get consent as a substitute for ensuring that participants can control the use of data about them.

Consent forms, particularly for pharmaceutical research, can become so long and detailed that they are as likely to confuse people as to assist them making choices. The purpose of these forms is not so much to enhance the quality of decision making as to transfer the risks involved in trials to the research subjects. As if to say that 'the participants knew this might happen, because we told them, so they willingly ran the risks and we cannot be blamed if they materialise'. One fifteen year old interviewed by Priscilla Alderson about consent to surgery captured this with the acute insight that children often bring:

Its not the doctors' fault if something goes wrong. Your parents are to blame, because they've signed the form, it would be their fault. ${ }^{15}$

Consider the so-called 'informed refusal forms' where in effect patients are asked to sign to show that they accept the risks of rejecting professional advice. Lord Donaldson expressed his criticism of this development in the following terms

It is clear that these forms are designed primarily to protect the hospital from legal action.... [they should] separate the disclaimer of liability on the part of the hospital from what really matters, namely the declaration by the patient of his decision with a full appreciation of the possible terms... ${ }^{16}$

Consent in the hands of these legal advisers is not about promoting the moral value of autonomy but about removing the need for health professionals to take responsibility for treatment being in the interests of their patients by transferring that responsibility to them. The moral value of autonomy is not in fact promoted and the moral purpose of health care is obscured.

\footnotetext{
${ }^{15}$ Quoted in P. Alderson \& J. Montgomery, Health Care Choices: Making decisions with children (London: Institute for Public Policy Research 1996) at p 45.

${ }^{16}$ Re T (adult: refusal of medical treatment) (1992) 9 BMLR 46, 61.
} 
Hence, my title refers to the 'de-moralisation' of medicine. I shall be drawing attention to some of the ways in which the scope for moral reflection and action is being reduced by developments in the operation of health care law. I will further suggest that the results of this process is thoroughly demoralising for those in the health professions - threatening to rob them of their rationale for coming to work in health services in the first place. If the law is to blame, even in part, for these twin processes of demoralisation, then it can fairly be criticised.

But, I shall also seek to explain why I do not believe we should despair. Rowan Williams went on to argue that the retreat of the state from the sphere of values was an opportunity for traditions, especially from his perspective religious traditions, that enshrine and embody a system of values to be revitalised as playing a central role in community life. I want to consider whether there is a similar opportunity for maintaining a system of values within health care, and specifically what role lawyers and the law might have to play in that process.

\section{The changing role of litigation}

My concern about the way in which the law is impacting on health care can also be drawn out from a consideration of the way in which the law is used by campaigning groups. While it sometimes has arbitrary and distorting elements, ${ }^{17}$ litigation can be seen as one of the ways in which the nature and values of the law can be established and shaped. Derek Morgan and Bob Lee have developed the concept of a 'stigmata case' to capture this process. ${ }^{18}$ Such cases have five features. ${ }^{19}$ They are relatively novel and ethically controversial; raise the balance of personal interests and public interest; force us to consider the goals of medical practice; they offer an opportunity to take stock of the boundaries between the anomalous and routine, the normal and the pathological; and they require the courts to develop a social, even moral, vision to respond to the social and cultural revolution of contemporary medicine.' Morgan and Lee cite as examples of such cases those of Tony Bland, Diane Blood, and the conjoined twins known as Jodie and Mary. ${ }^{20}$

The essence of a 'stigmata case' is that it enables the marks of a deeper system of values to be seen on the surface of a specific dispute. ${ }^{21}$ Its resolution will tell us something about the society in which we live as well as establishing what steps need

\footnotetext{
${ }^{17}$ I. Kennedy \& J. Stone 'Making public policy on medico-moral issues' in P. Byrne (ed) Ethics and law in health care research (London: King's Fund 1990); P. Alderson \& J. Montgomery, Health Care Choices: Making decisions with children (London: Institute for Public Policy Research 1996) at pp 389.

${ }^{18}$ D. Morgan \& R. Lee, 'In the name of the father? Ex p Blood: Dealing with novelty and anomaly' (1997) 60 MLR 840.

${ }^{19}$ R. Lee \& D. Morgan, 'Regulating Risk Society; stigmata cases, scientific citizenship and biomedical diplomacy’ (2001) Sydney Law Review 297-318.

${ }^{20}$ Airedale NHS Trust v. Bland [1993] 1 All ER 821, R v Human Fertilisation and Embryology Authority, ex p Blood [1997] 2 All ER 687, Re A [2000] 3 FCR 577.

${ }^{21}$ The metaphor is drawn from the phenomenon sometimes reported in the Christian religious tradition where the wounds received by Christ on the cross appear on the bodies of believers, seen as the external manifestation of an ecstatic religious experience.
} 
to be taken. ${ }^{22}$ Thus, litigation provides a context in which the values of a society can be expressed and also a mechanism whereby clashes of competing values can be resolved. However, a new type of case is emerging that actually obscures such value conflicts and in which the translation of conflict into the discourse of law excludes moral debate rather than enables it to be addressed. If this type becomes the norm, then once again, more law turns out to mean less morality.

In their later assessment of the concept of the 'stigmata case', Morgan and Lee suggested that it needed to take more account of the issue of the allocation of the power to decide. ${ }^{23}$ The case of the conjoined twins, they argue, effectively results in the delegation of control to the doctors. Such delegation could be said to be one of the defining characteristics of an integrated approach to law, morality and medicine whereby a framework is developed to promote recognition of the moral choices to be made but not to dictate outcomes. This model is explored further below, together with its manifestation in the style of judging adopted by some members of the bench. However, resolving disputes by delegation to a chosen decision-maker, rather than addressing the substantive issues, reduces the extent to which the moral conflicts that are exposed by stigmata cases appear in the corpus of the legal rules. While the event of litigation may give rise to the social phenomenon described by Morgan and Lee, it is far from clear that it can be seen within the discourse of the law itself. The recognition that the identification of decision makers is one of the key functions of health care law has led to the emergence of test case litigation seeking to challenge precisely the allocation of power. This is not new, but what is changing is the nature of the connection between law and morality that such cases expose.

The most famous early test case in this area is probably that brought by Victoria Gillick in $1984 .^{24}$ She challenged a health service circular that advised doctors that they could give advice to and prescribe contraception for young people without the involvement of their parents. From that litigation emerged the concept now generally known as 'Gillick competence' and a debate over the nature of parental responsibility which has shaped the status of young people in health services for the past two decades. $^{25}$

This case carried many of the 'stigmata' that we have referred to. It forced a reconsideration of the relationship between parents and children, an assessment of how health professionals should relate to families, and required an examination of the potential criminal liability of health professionals for doing what they regarded as their moral duty. Mrs Gillick brought a hypothetical action, in that none of her own children were in fact said to be seeking treatment at the time. Nevertheless, she argued an unashamedly substantive case. ${ }^{26}$ She asserted that parents had the right to take

\footnotetext{
${ }^{22}$ There are some parallels here with the account of Mary Ann Glendon's book Abortion and Divorce in Western Law (Cambridge, Mass.: Harvard University Press 1987) in which the theories of the anthropologist Clifford Geertz are used to show how laws can be seen as a way in which societies project their values.

${ }^{23}$ R. Lee \& D. Morgan, 'Regulating Risk Society; stigmata cases, scientific citizenship and biomedical diplomacy' (2001) Sydney Law Review 297-318, 298 fn 6.

${ }^{24}$ Gillick v W. Norfolk AHA [1985] 3 All ER 402.

${ }^{25}$ See P. Alderson \& J. Montgomery, Health Care Choices: Making decisions with children (London, Institute for Public Policy Research 1996.

${ }^{26}$ For a more detailed examination of the legal nature of her claims, see J. Montgomery 'Children as Property?' (1988) 51 MLR 323-342.
} 
decisions about their children's lives and called upon the law to back her in her claim by requiring doctors to defer to the parents rather than treat young people as patients in their own right. When she lost, the rights of young people were established and the implications of the recognition that our society valued the autonomy of young people began to be worked through in policy, practice, legislation and the courts.

Compare this to the recent spate of litigation brought by the Pro-Life Alliance challenging the authority of the Human Fertilisation and Embryology Authority. That Authority was set up to regulate the provision of fertility services and oversee embryo research following a protracted policy making process taking the best part of a decade. ${ }^{27}$ The basic structure of the system established under the Human Embryology and Fertilisation Act 1990 is that the Authority is empowered to determine what treatment and research is permitted, within limits set by Parliament, through a licensing system. ${ }^{28}$ The Act prohibits certain practices absolutely, and prohibits others unless they are licensed. Practices outside the scope of the Act are unregulated and governed by more general principles of health care law including the requirement of consent. The overarching tort of negligence would provide compensation where professionals act in ways unacceptable to their peers.

The effect of this scheme is to entrust to the members of the Authority the power and responsibility to determine what morality requires. The statute and the regulations made under it indicate what our elected representatives have identified as key moral boundaries and issues. The licensing powers of the authority permit it to establish further moral norms through the imposition of conditions and the development of the Code of Practice. This flexible framework has enabled issues such as the provision of services to single women and same sex couples to be worked through without the need for further legislative activity.

In 2003, the judicial committee of the House of Lords considered the place of cloning in this scheme. ${ }^{29}$ It was suggested by the ProLife Alliance that human cloning using a process called cell nuclear replacement was outside the scope of the Act and could not be licensed by the Authority. In some respects the case is extremely interesting as an example of statutory interpretation. The House of Lords construed the statute purposively, finding that, despite the detailed arguments on drafting pointing in a different direction, the general intention of Parliament was clear. This was that it wished decisions on the use of reproductive technology to be made by the Human Fertilisation and Embryology Authority. Consequently, the House of Lords found that cloning by cell nuclear replacement fell within the scope of the Act, giving the HFEA the power to regulate it.

For the purposes of this piece, the most interesting feature of this case is the way in which the substantive moral debate over the ethics of cloning was excluded from the

\footnotetext{
${ }^{27}$ R. Lee \& D. Morgan, Human Fertilisation and Embryology: Regulating the Reproductive Revolution (London, Blackstone Press 2001) provides the best general study of the Act and its operation. See also the report of the House of Commons Committee on Science and Technology, Human Reproductive Technologies and the Law HC 7 2004-5.

${ }^{28}$ J. Montgomery, 'Rights, restraints and pragmatism' (1991) 54 MLR 524-534.

${ }^{29} R$ (on the application of Quintavelle(on behalf of ProLife Alliance)) $v$ Secretary of State for Health [2003] UKHL 13, [2003] 2 All ER 113. See also $R$ (on the application of Quintavelle) v HFEA [2002] EWCA 667, [2003] 3 All ER 257 on the power to license tissue typing.
} 
litigation. The ProLife alliance found itself putting forward the case that cloning by the CNR process was not within the scope of the 1990 Act. This was bizarre given that the consequence of that argument would be that there was no regulation of such cloning in humans and it could therefore be carried out without restriction. The moral stance of the ProLife Alliance was that no cloning should take place at all, but it found itself making an argument that it should be removed from regulation. Equally, the speeches in the House of Lords turn on legalistic arguments of construction and do not examine the substantive moral debates about cloning.

In contrast to Gillick, there is a shift here; from the focus of litigation being on substantive moral arguments to issues of formal legitimacy. The legitimacy or otherwise of the power of the HFEA to regulate cloning is assessed by reference to the legal pedigree of its authority - the intention of the legislator - not the nature of the issue itself. This is a classic strategy of legal positivism, an approach to legal theory that seeks to argue that legal legitimacy and moral authority need to be considered separately not as an integrated activity. ${ }^{30}$ Where the approach holds, the stigmata of our value system will no longer appear on the bodies of our judgments. The morality will be sucked out of them.

In the light of this perspective, was the Blood litigation really a 'stigmata Case' or should it be seen as part of the demoralisation process? There are aspects of both. Dianne Blood's main challenge to the statutory regime concerned its consent provisions. She claimed that her deceased husband wanted her to be able to conceive children using his sperm, even if that had to occur posthumously. Her evidence was that they had discussed the possibility so that she knew what he would have wanted. Her difficulty was that the legislation required written consent before this was permissible. On her account, it was only because Stephen Blood's death had been unexpected that no such record had been made. She suggested that the formality of writing was subsidiary to the key principle of consent and that she should therefore be permitted to use his sperm to seek to establish a pregnancy. In substantive terms, this aspect of the case touches on the proper balance between the general public interest in certainty and the private interests of the individual.

A second aspect of the case also seems properly assigned to the stigmata category the question of whether it was lawful to remove sperm samples from Stephen Blood's body either when he was in a coma or possibly after his death. This raises profound questions about the acceptability of an intervention made not to benefit the patient, but to enable his wife to make choices about her future life without him. Here, again the legal precedents were against Dianne Blood. The only recognised justification for treatment without consent, outside of statutory framework for compulsory mental health treatment, was the interests of the patient. ${ }^{31}$ Questions as to whether this properly reflects our social values in relation to family membership, or when proper respect for human bodies after death is compatible with donation of organs or samples are properly seen as carrying the moral significance that marks out 'stigmata cases'. ${ }^{32}$

On each of these 'stigmata' issues, Dianne Blood lost her case. The Court of Appeal found that the samples were taken unlawfully and that there could be no dispensation

\footnotetext{
${ }^{30}$ J. Raz, The Authority of Law (Oxford: Oxford University Press 1979).

${ }^{31}$ F v W Berkshire HA [1989] 2 All ER 545.

${ }^{32}$ These issues were debated in Parliament in consideration of the Human Tissue Act 2004.
} 
from the statutory requirement of written consent. The moral policy enshrined in the law was upheld. Yet, Dianne Blood is now the proud mother of two children and has secured legislation to amend the law to enable them to be registered as the children of their dead father. ${ }^{33}$ The Court of Appeal held that she was entitled to take the unlawfully obtained sperm abroad to a clinic in Europe. The fact that she could win her case despite the morality-based legal arguments going against her raises the third illustration of the increasing demoralisation of health care law. She won her case by arguing that the issues before the court should be seen as concerning the freedom of the European market in services. Although the final decision was left to the HFEA to make, as it had not previously taken this dimension into account, the Court of Appeal indicated that it was unlikely that Dianne Blood's case could be resisted. ${ }^{34}$ An apparently quintessential 'stigmata case' transmuted into a market issue where public policy is of limited if any relevance. This enabled the public sympathy for Mrs Blood's position to be assuaged without altering the principles enshrined in the law. However, it meant that the stigmata of the underlying issues were manifested only in the solution to the specific case, not in the legal rules (which were preserved untouched). Thus, the link between moral debate and legal doctrine was severed.

\section{Health care in the market}

The use of EU law on the common market has a broader significance for the development of health care law. Bobbitt has warned that the dominance of the market has undermined the legitimacy of government policy in areas of morality. Health care law based on a market model is likely to bring similar impotence. For those with money, choice over access to health services has long been wider than for the poor. But the nature of this extension is changing. It is no longer merely an issue of speed of access, range and possibly quality of services. What is now emerging is the impact of the market in health services on what have been traditionally seen as major matters of domestic policy. The Blood case shows that a determined woman with money can evade the policy restrictions established by Parliament over the availability of posthumous conception. As Margaret Brazier and Nicola Glover have pointed out, restrictions on the availability of Viagra by making it a prescription-only medicine are easily evaded by those with internet access and a credit card. ${ }^{35}$ The prohibition on euthanasia in the UK can now be evaded by travelling to Switzerland. ${ }^{36}$

The impact of market consumerism on UK health care law has been limited to date because the vast majority of care is delivered through the National Health Service and the courts have resisted the concept of entitlements to care. When the father of Jaymee Bowen sought to use the courts to force Cambridge Health Authority to fund treatment for his daughter he found that the Court of Appeal believed that judges should not be drawn into disputes over the allocation of resources and should be wary of intervening into clinical matters, which were properly within the scope of medical

\footnotetext{
${ }^{33}$ Deceased Fathers Act 2003.

${ }^{34} R$ v Human Fertilisation \& Embryology Authority, ex p Blood [1997] 2 All ER 687, 700.

${ }^{35}$ M. Brazier \& N. Glover, 'Does Medical Law have a Future?' in D. Hayton (eds) Law's Future(s) (Oxford, Hart Publishing 2000).

${ }^{36}$ The High Court has found that local authorities are not obliged to seek to prevent such travel by people within their care, news report, Times 1 December 2004.
} 
discretion. Although the clinical issues were clearly controversial, in the light of the disagreements exposed by Jaymee's situation, the Court of Appeal took the view that judges should not override the clinical assessment made by the Cambridge Health Authority. ${ }^{37}$ The High Court judge, Laws J, felt that insufficient regard had been paid to the human rights issues raised, ${ }^{38}$ but the Court of Appeal declined to juridify the issues into matters of rights. Instead, it preferred to focus on the exercise of discretion in the performance of public powers.

However, the situation is changing for reasons of both law and policy. So far as policy is concerned, the Government plans to significantly increase the extent to which health services are delivered by a mixed economy by ensuring that patients are able to choose where they receive their treatment from a range of providers, including at least one from the independent sector. A system of tariff prices has been developed to enable such providers and NHS bodies to compete for patients on an equal financial basis. 'G9 'Guarantees' of treatment within specific time limits are to be offered, moving towards an ideology of entitlement to services rather than seeing patients as the passive recipients of state beneficence.

Interesting questions will arise as to the enforceability of such guarantees. ${ }^{40}$ Even now, however, there are indications that at least some members of the judiciary are prepared to explore the potential for enforceable legal rights. In $R$ (Burke) $v G M C$ Munby $\mathrm{J}$ referred to a right to require treatment in a hypothetical context. ${ }^{41}$ More concretely, he considered the issues in the case of Mrs Yvonne Watts. ${ }^{42}$ Mrs Watts sought reimbursement from her local primary care trust of the cost of hip replacement treatment she had received in France on the basis that she was entitled to the treatment under the NHS. She had made the arrangements to be treated in France after having been told that she would need to wait approximately one year before the NHS would be able to carry out the operation.

The Yvonne Watts case raises similar ambiguities to that of Jaymee Bowen. Should it be seen principally as a resource allocation issue - concerned primarily with money not people, pitting faceless 'men in grey suits' against vulnerable patients facing death or chronic and agonising pain? Or was the issue one of clinical judgment, concerning the assessment of the needs and interests of patients? Because, like Jaymee Bowen's case, the issue concerned the funding of a specific procedure under a specific contract with an external health provider the issues can be seen more starkly than in general decisions about prioritisation of patient groups in block commissioning arrangements.

The view of Yvonne Watts' daughter was that surgery was urgently needed. This was reinforced by the assessment of the anaesthetist consulted in France, who expressed

\footnotetext{
${ }^{37} R$ v Cambridge HA, ex p $B$ [1995] 2 All ER 129.

${ }^{38} R$ v Cambridge DHA, ex p $B$ [1995] 1 FLR 1055.

${ }^{39}$ The NHS Improvement Plan: Putting People at the Heart of Public Services (2004) Cm 6268;

Reforming NHS financial flows introducing payment by results (London: DoH 2002).

${ }^{40}$ See the discussions of similar issues in the context of the NHS 'internal market' of the 1990s by J Jacob 'Lawyers go to hospital' [1991] Public Law 255-81 and K Barker 'NHS contracting: shadows in the law of tort?' (1995) 3 Med. L. Rev 161-76.

${ }^{41}$ [2004] EWHC 1879, see further below. This point did not find favour with the Court of Appeal, see [2005] EWCA Civ 1003, para 31.

${ }^{42} R$ (Watts) v Bedford PCT and Secretary of State for Health [2003] EWHC 2228.
} 
concern that unless surgery was carried out by the middle of March 2003 there was a risk that Mrs Watts would be too weak to have it. ${ }^{43}$ The view taken by the doctors in Bedford was different. Originally, Mrs Watts was assessed as a 'routine' case - as deserving but no more deserving than other patients awaiting treatment. After a reassessment in accordance with the direction of the High Court, the English surgeon felt that Mrs Watts' condition had perhaps deteriorated more quickly than he might have expected so that she should be treated 'soon' rather than as a routine patient. However, her case was still not felt to be 'urgent'. The English consultant anaesthetist felt that Mrs Watts remained fit for surgery and was likely to remain so (a less pessimistic view than his French counterpart). While patients classified as routine cases would have expected to receive their surgery within 12 months, those to be treated 'soon' should have been operated on in 3-4 months. In Mrs Watts' case the reclassification meant that the operation would have been carried out under the NHS in April or May 2003.

This reclassification meant that Mrs Watts failed in her claim for reimbursement, as she would have been treated within an acceptable time. However, she won the more important arguments about the impact of European Union law on the legal

framework. Munby $\mathbf{J}$ recognised that it was clearly established that domestic law did not provide Mrs Watts with any remedy against the refusal to prioritise her case and to give her the operation she sought within the timescale that she and her daughter thought appropriate. ${ }^{44}$ Thus, any remedy provided by European law that required the provision of treatment would represent a significant change to legal structure of the NHS. ${ }^{45}$ However, he was prepared to find that European law required the NHS to pay for treatment in another member state if a patient faced 'undue delay' in receiving it in her own country. This held even though there could be no such requirement for reimbursement for the cost of private treatment in the UK. ${ }^{46}$ This creation of a right to treatment is the first important feature of the dawning new approach to health care law of which the Watts case may be the harbinger.

The second concerns the rejection of the conceptualisation of health care law as an aspect of welfare law. It is interesting to note the important differences between Art 49 of the EC Treaty, on which the Watts case turned, and Article 22 of Council Regulation 1408/71. The former is an economic provision that aims to secure the free market in services and therefore protects the commercial interests of health service providers to be able to market their services across the European Union. The latter protects the beneficiaries of social security systems when they seek treatment in another member state.

\footnotetext{
${ }^{43}$ [2003] EWHC 2228, para 19. It should be noted that this was the account given by Mrs Watts' daughter, but that no medical evidence was filed to this effect from the French doctors because they declined to accept Mrs Watts as a patient once they were asked to supply information for court purposes, see para. 20.

${ }^{44}$ Para 43, after reviewing $R v$ Cambridge HA, ex p B [1995] 1 WLR 898 and $R v N W$ Lancashire HA, ex A [2000] 1 WLR 977.

${ }^{45}$ I have explored these issues in J. Montgomery 'The Impact of European Union Law on English Health Care Law' in M Dougan \& E Spavanta (eds) Social Welfare and EU Law (Oxford, Hart Publishing 2005).

${ }^{46}$ This is the clear implication of $R$ v Cambridge HA, ex p $B$ [1995] 2 All ER 129 where such private treatment was given after funding from an anonymous donor.
} 
Article 22(2) was redrafted in 1981 to ensure that member states retained the ability to determine the scope of treatment and to manage resources. ${ }^{47}$ The Article deals with circumstances when member states are obliged to authorise treatment in other countries under their welfare schemes. The original wording of the provision required authorisation to be given for treatment abroad whenever it '[could] not be provided for the person concerned within the territory of the Member State where he resides.' The current drafting deliberately extended the discretionary power to grant or refuse authorisation to enable management through prioritisation of patients in terms of time, taking into account clinical need. ${ }^{48}$ It reads

\begin{abstract}
"The authorization required under paragraph 1(c) may not be refused where the treatment in question is among the benefits provided for by the legislation of the Member State on whose territory the person concerned resided and where he cannot be given such treatment within the time normally necessary for obtaining the treatment in question in the Member State of residence taking account of his current state of health and the probable course of the disease."
\end{abstract}

Thus, where health care law is seen as a matter of social welfare provision managerial and clinical discretion are seen as essential to the regulatory framework.

In the Watts case, however, the High Court concentrated on the provisions of Article 49 , conceptualising the case as one about restriction of the right to trade in health services. Munby $\mathbf{J}$ noted that various arguments that health services should not be regarded as simply another form of commercial enterprise had been rejected in a series of cases before the European Court of Justice. The argument that Article 49 was not applicable to social security was rejected in Kohll $v$ Union des caisses de maladie. ${ }^{49}$ The suggestion that it was not applicable to hospital services in general was rejected in Vanbreukel $v$ Alliance nartionale des mutualities chretiennes. ${ }^{50}$ In Geraets-Smits v Stichtung Ziekenfonds VGZ; Peerbohms v Stichting CZ Group Zorgverzekeringen the European Court of Justice had gone further still and found that Article 49 was applicable to hospital services even when they were provided free of charge, rejecting the suggestion that such benefits in kind were not to be seen as an 'economic activity'. ${ }^{51}$ Finally, in Muller-Fauré v Onderlinge Waarborgmaatschappji OZ Zorgverzekeringen UA; van Riet v Onderlinge Waarborgmaatschappji OZ Zorgverzekeringen UA the ECJ reiterated this view despite the attempts by the UK government and others to distinguish social insurance systems that provide only treatment and not financial benefits. ${ }^{52}$

Munby J rejected the UK government's attempts to distinguish the NHS system as 'technical' and 'marginal' points. ${ }^{53}$ The two arguments offered were, firstly, that the NHS provided care itself (in the overwhelming majority of cases) and, secondly, that its doctors are salaried employees and were not reimbursed on a piecework basis

\footnotetext{
${ }^{47}$ The current form of Article 22.1 was inserted by Council Regulation 2793/81.

${ }^{48}$ One of the preambles to the regulation indicates that this extension was seen as a necessary improvement gained from experience in implementing the original Regulation. See the Court of Appeal's comments in Secretary of State v R (Watts) [2004] EWCA Civ 166, para [36].

${ }^{49}$ [1998] ECR I-1931.

${ }^{50}$ [2001] ECR I-5363.

${ }^{51}$ [2002] QB 409.

${ }^{52}$ Case C-385/99

${ }^{53}$ [2003] EWHC 2228, para. 97.
} 
against a preset scale of fees (as in the Dutch system reviewed in Geraets-Smits). However, these could reasonably be seen as illustrations of the way in which NHS care is not conceptualised as an economic enterprise. That this is true in a legal as well as political sense can be shown by the lack of enforceability of rights to provision, already noted, and also in the approach to 'prior authorisation' of treatment.

The High Court in Watts cited arguments used in the Kohll that European law precluded states making treatment abroad subject to prior authorisation when costs incurred within the member state are not subject to the need for such advance approval. ${ }^{54}$ In relation to the NHS, however, reimbursement within the state is subject to prior authorisation, as the Jaymee Bowen case shows. Indeed, in a weaker, but nevertheless important sense, the role of GPs as gatekeepers means that there is a system of prior authorisation for all NHS treatment, in that access to care (other than accident and emergency services) is dependant on a medical assessment of need by someone authorised by the state to commit public resources. The fundamental flaw in the reasoning process is to neglect the mechanisms for accessing treatment within the UK under the NHS system. The assumption on which the EU law is based is that it is not legitimate to raise higher barriers to the provision of service in other member states than would exist in relation to the member state in question. There is no discussion, however, of the actual barriers that exist within the member states.

The decision in Vanbreukel emphasises that a lower level of cover for treatment abroad than at home is an unlawful restriction on freedom of services. There needs to be 'at least an equally advantageous level of cover' or else an objective justification for difference. ${ }^{55}$ Yet, this does not deal with the situation where there is no guarantee even at home. In that context, there is no lower level of cover for treatment abroad because the patient's lack of entitlement applies equally at home as well as overseas. The neglect of this point is understandable in a number of the ECJ cases, including Gereats-Smits and Peerbohms because the treatment in question was not available at all in the state of residence. However, it is problematic where the ability of member states to manage the services that they provide within their domestic health systems is compromised by exposure to market disciplines that make the provision of treatment follow from the demands of patients rather than a clinical assessment of need and priority.

This debate can clearly be linked with the thesis of this paper on the 'demoralisation' of health care as a consequence of engagement with the law. In a socialised health care system such as the NHS, the just management of resources and the balance to be struck between comprehensive provision for all and quick access for a few are matter for public policy and debate about the principles on which the NHS is founded. The arguments offered by the UK government in Muller Faure stressed the general economic impact of European law, undermining the balance of the system and depleting resources for more urgent treatment. ${ }^{56}$ They did not offer an argument from fairness: that management of waiting lists was a form of prioritisation that sought to balance the competing interests of patients for resources. While the moral problems of rationing are generally masked under the guise of clinical judgment, decisions by

\footnotetext{
${ }^{54}$ [1998] ECR I-1931 at para [34], cited in Watts at para 113.

55 [2001] ECR I-5363 at para 44, 46; cited in Watts at para 114.

${ }^{56}$ Case C-385/99. These arguments are reviewed in Watts para 102.
} 
clinicians as to the urgency of care are the main means by which resource allocation is related to the moral claims of patients to priority treatment. Precluding such judgments by allocating resources on demand undermines the opportunity for ethical decision making. It is a further example of the displacement of moral arguments in favour of legal entitlements that are blind to many of the relevant factors.

It is important to note that this is just as much a victory for health providers as a matter of patients' rights. The spending of public money on health services becomes provider led in that those hospitals that can attract demand can then require NHS funds to be allocated to pay for care irrespective of whether the relevant PCT's planned activity for that type of care has been exceeded. The allocation of expenditure to particular types of care is a mechanism for relative prioritisation of that care to other calls on health expenditure. Thus, forcing more expenditure on hip replacements provided abroad will alter the ability of the NHS to choose how much to spend on this type of care and reduce the amount available for other forms of care less amenable to marketing such as mental health.

The Watts case is thus an illustration of the dangers of rights based systems in threatening to distort priorities. ${ }^{57}$ Ms Watts's daughter was pushing for the PCT to fund overseas treatment even before the GP had written a letter referring her mother to the consultant. She knew about and raised the Geraets-Smits case with the PCT and the Department of Health and she was persistent in her championing of her mother's position. She was well informed about the mechanisms to secure treatment overseas, both within the NHS and through the use of a specialist health logistics company, which arranged for treatment in a French clinic. ${ }^{58}$ This was not in fact a case of a patient despairing after learning how long they would have to wait, but of an enterprising woman playing the system intelligently to maximise her mother's interests. This illustrates the likely impact of the system suggested by the Watts decision: one based on entitlements to care, tradeable in the market through what is effectively a voucher system. It will benefit those skilled at using markets, both patients and health providers. It will do so at the expense of distributive justice, once again undermining the ability of the NHS to pursue moral principles.

This was well understood by the Court of Appeal in Watts. ${ }^{59}$ Mirroring the approaches seen in the different levels of court in the Jaymee Bowen case, the terms in which the Court of Appeal referred the issues to the European Court of Justice show how it conceptualised the case from the perspective of service provision rather than individual rights. Munby J considered whether Mrs Watts would only receive services after an unacceptable delay, examining her position without regard to that of other potential patients. He was even prepared to override managerial and clinical discretion about priority by forming his own view of what constituted an unacceptable delay, rejecting the more traditional deference to clinicians on such matters. The Court of Appeal drew the attention of the ECJ to whether patients should be permitted to jump the queue by having recourse to law and whether it was appropriate for the courts to dictate how governments should allocate resources. Similarly, in the earlier

\footnotetext{
${ }^{57}$ For an earlier discussion of the risks of 'rights' in this respect, see J. Montgomery 'Patients First: The role of rights' in K. Fulford, S. Ersser \& T. Hope (eds) Essential Practice in Patient-Centred Care (Oxford, Blackwell Science 1996).

${ }^{58}$ See [2003] EWHC 2228, para 27.

${ }^{59} R$ (Watts) v Secretary of State for Health [2004] EWCA Civ 166.
} 
case, Laws $\mathbf{J}$ had seen the issues as revolving around the human rights of Jaymee Bowen, but the Court of Appeal had understood the focus of the case to be the proper management of scarce resources. In both cases, the Court of Appeal has showed itself reluctant to regard rationing issues as justiciable.

The question of what approach judges should take depends very much on their understanding of the relationship between law and health care practice. I have argued that there is a common theme to be seen in the use to which consent law has been put, the changing nature of test case litigation, and the emerging interest in the application of EU single market rules. That theme is that substantive moral debates are becoming more difficult to accommodate within the discourse of law. Whether and how this matters depends on an analysis of the desired connection between law and morality.

\section{Modelling morality in medical law}

Not all ways of thinking about the relationship between law and health care practice exclude morality. Much depends on the assumptions that we make about the nature of the disciplines concerned. The issues were opened up by Jo Jacob of the LSE in his suggestion that we should consider three models of the practice of medicine. ${ }^{60}$ Two of them, 'scientific medicine' and 'participatory' medicine, are built on the basis that medicine is a tool that needs to be directed. The implication is that understanding of the techniques to be used draws on a different sphere of knowledge than does the wisdom required to work out how and when they should be used. The first is technical domain, where the health care professionals are expert. The second is a sphere in which the claim to expertise can be spread more widely. The difference between the two models is that in the former the direction is given by the doctor, whereas in the latter it is shared between patient and doctor.

It is this separation that has made the demoralisation process possible. It focuses our interest on who decides and encourages us to see health professionals as technicians. Thus, Ian Kennedy (now Sir Ian) once argued that 'it is not for professionals to set the moral agenda for their relationship with those they serve. They have only extra duties, not privileges. ${ }^{61}$ This analysis has encouraged medical law scholars to concern themselves with techniques that aim to limit the power of health professionals to areas of technical expertise. Thus, Kennedy went on to argue, 'the advice which is the professional preserve of the doctor is that which is involved in treatment - advising as to what, if anything, can be done.... Rather than advice, what is really involved is information. ${ }^{62}$ Interestingly, he took a rather different view of what solicitors do. The advice given by a doctor is merely information about possibilities, not advice as to what it would be wise to do, but interestingly 'advice giving is to a solicitor what diagnosis and treatment are to a doctor: namely what their skill consists in. ${ }^{, 63}$

\footnotetext{
${ }^{60}$ J.M. Jacob, Doctors and Rules (London, Routledge 1988). I discussed this book, and set out the arguments summarised here in J. Montgomery, 'Medical Law in the Shadow of Hippocrates' (1989) 52 MLR 566-576.

${ }^{61}$ I. Kennedy 'The Patient on the Clapham Omnibus' in Treat Me Right (Oxford, Oxford University Press) 178. Originally published in (1984) 47 MLR 454.

${ }^{62}$ Ibid. 182-3

${ }^{63}$ Ibid. 182.
} 
Kennedy was attacking the approach, explicitly taken by Lord Diplock in the Sidaway case that the practice of doctors should be considered generally and not subdivided so as to enable different aspects of health care to be judged against different types of test. ${ }^{64}$ In all aspects of their work, Diplock held, professionals should be judged against prevailing professional norms - were their actions regarded as acceptable practice by a responsible body of professional opinion? This is the standard known as the Bolam test after the case in which it was first formulated. ${ }^{65}$ The indivisibility of the professional duties of doctors (and other health workers) is key feature of what might be described as an integrated model of the relationship between technical skill and moral reasoning. On this model, moral reasoning is seen as an essential part of the practise of health care not some external process applied to it. This leads naturally to an integrated model of the relationship between health care law and morality in which it is assumed that professional practice already takes into account the moral dimension and approaches its regulation on that basis. Thus, reinforcing prevailing professional standards is also to reinforce moral practice.

Such a model can be seen as pervading much of English health care law. ${ }^{66}$ The House of Lords has applied the Bolam test in ascertaining the scope of obligations to keep people alive and maintaining their capacity to reproduce - matters that relate to the fundamental human rights to life and to found a family. ${ }^{67}$ Legal regulation of access to abortion services is determined by whether doctors are acting in 'good faith' when they consider the questions set out in the legislation, not by direct consideration of those questions. ${ }^{68}$ The legal definition of death operates by incorporation of medical practice not by imposition of an external definition. ${ }^{69}$

Although influential with judges, this integrated model has been seen as highly unsatisfactory by many academic and practising lawyers. ${ }^{70}$ The divisibility of professional functions would enable the law to drive medical practice from being 'scientific' and doctor directed towards being 'participative' or patient directed. Health professionals will recognise the pattern here. There are close analogies with the drive for a stronger evidence base for practice; which (for all its virtues) reduces the role for individual clinical judgment. Increasing development of the scientific basis for practice also increases the ability to transfer power across to patients. Information can be made available to and used by patients, in turn making the delivery of care more responsive to patient choice.

But for Jacob, the understanding of the nature of medicine on which his first two models operated failed to recognise the cultural context in which doctors are trained and socialised. He suggested that more regard needed to be had to the 'classical' or 'Hippocratic' model of medicine, as he called it. He argued that professional knowledge, experience and values are all inculcated in an integrated process of

\footnotetext{
${ }^{64}$ Sidaway v. Bethlem RHG [1985] 1 All ER 643.

${ }^{65}$ Bolam v. Friern HMC [1957] 2 All ER 118, 121.

${ }^{66}$ J. Montgomery, 'Medicine, Accountability and Professionalism' (1989) 16 JLS 319-339.

${ }^{67}$ Airedale NHS Trust v. Bland [1993] 1 All ER 821, F v. W. Berkshire HA [1989] 2 All ER 545, ECHR arts 2 \& 14.

${ }^{68}$ Abortion Act 1967, s 1.

${ }^{69}$ Human Tissue Act 1961.

${ }^{70}$ I have illustrated this in J. Montgomery, 'Time for a Paradigm Shift? Medical Law in Transition' (2000) 53 Current Legal Problems 354-408, esp. 373.
} 
training and apprenticeship. This is still a pretty accurate description of how much medical education operates. Classroom and practical learning are both essential parts of the curriculum. Despite the specific teaching of medical ethics, and to some extent law, medical students still learn most of what they know about medical ethics from their experience of practice.

Jacob argued that within the Hippocratic tradition, the separation of the process of determining what could be done from what should be done (on which the alternative models rely) was not recognised. The practice of medicine, on his view, itself enshrined a collegiate value system. Thus, one could extrapolate from his argument that to use the Bolam test as a benchmark of acceptable practice was not to abandon normative judgment, as some have seen it, but to reinforce the values of the health professions. From this view, the ascendancy of the ideology enshrined in the Bolam test is a positive choice to build on the moral nature of medicine. ${ }^{71}$

Many aspects of the history of medical (or health care) law, and its scholarship, can be illuminated by these distinctions. For the bulk of the late Twentieth Century judicial views, whether expressed in court or 'extra-judicially' in lectures or writings, adopted the view that the key to success lay in supporting the enterprise of health care not challenging it. The judges adopted a view of health care professionals that justified the non-interventionist approach enshrined in the Bolam philosophy by reference to the 'professional' nature of medical and nursing vocations - highly skilled, dedicated and altruistic staff applying uncertain but technical knowledge for the benefit of patients. ${ }^{72}$ In one case, Mustill LJ indicated why permitting litigation against health professionals was worrying

If the unit had not been there, the plaintiff would probably have died. The doctors and nurses worked all kinds of hours to look after her baby. They safely brought it through the perilous shoals of its early life. For all we know, they far surpassed on numerous occasions the standards of reasonable care. Yet it is said that for one lapse they (and not just their employers) are to be found to have committed a breach of duty. Nobody could criticize the mother for doing her best to secure her son's financial future. But has not the law taken a wrong turning if an action of this kind is to succeed. ${ }^{73}$

On this view, delivering health care is an altruistic vocation not a commercial enterprise tainted by sordid financial pressures.

For the most part, judges gave similar accounts out of the court setting. ${ }^{74}$ They saw their function as enabling health professionals to perform their socially valuable work not to tell them how to do it. Thus, the paradox emerged that amidst clamours of the legal threat to medicine, ${ }^{75}$ legal commentators expressed some frustration with the

\footnotetext{
${ }^{71}$ I began to explore the possibilities of this corporate approach to professional values in $\mathrm{J}$. Montgomery, 'Time for a Paradigm Shift? Medical Law in Transition' (2000) 53 Current Legal Problems 354-408, 407-408.

${ }^{72}$ I set out this argument in detail in J. Montgomery, 'Medicine, Accountability and Professionalism' (1989) 16 JLS 319-339, see esp 327-331.

${ }^{73}$ Wilsher v Essex AHA [1986] 3 All ER 801, 810 (CA). The case proceeded to the House of Lords on the issue of causation.

${ }^{74}$ E.g. Sir Roger Ormrod, ‘A lawyer looks at medical ethics' (1978) Medico-Legal Journal 18-32.

75 J. Havard, 'The legal threat to medicine' (1982) 284 BMJ 612.
} 
hyperbole being offered. ${ }^{76}$ In fact, with its judicial face, the law supported medicine, looked favourably on its claims to the moral high ground and presented little threat to the autonomy of the professions or the hegemony of medicine.

This has begun to change. In 2001 Lord Woolf called for this attitude to be abandoned in a lecture entitled 'Are the courts excessively deferential to the medical profession? ${ }^{77}$ In the first few minutes he said that the answer was clearly yes. He drew heavily on the work of Ian Kennedy to indicate why that was so, and also on that of Margot Brazier, to suggest that things were beginning to change. While his evidence for change having already occurred was weak and unconvincing, ${ }^{78}$ the fact that so senior a judge called for it is highly significant. It may herald a shift in the nature of judging that could play a major role in what I have called the demoralisation process. To see how this could occur, it is necessary to consider the varied approaches that judges have taken to medical cases.

\section{Two types of judging}

Two approaches can be considered. In the first, the judiciary has sought to construct the legal framework within which health professionals work in such a way as to free them from detailed scrutiny. When courts are required to take decisions in difficult cases, they have generally been reluctant to codify principles preferring to use the concept of best interests as a way to resolve individual disputes without articulating precise legal rules. In the heyday of judicial non-intervention, judges were sometimes quite open about the importance they attached to enabling health professionals, usually doctors, to practise free from the worry of legal scrutiny. Lord Denning can be seen as epitomising this approach. ${ }^{79} \mathrm{He}$ has argued that it was necessary to "say and say firmly, that in a professional man, an error of judgment is not negligent. ${ }^{80} \mathrm{~A}$ charge of negligence in his view 'stood on a different footing to a charge of negligence against a driver of a motor car'. The consequences were far more serious. It affected his professional status and reputation. ${ }^{81}$ Legal liability for doctors would mean that 'a doctor examining a patient, or a surgeon operating at a table, instead of getting on with his work, would be for ever looking over his shoulder to see if someone was coming up with a dagger - for an action for negligence against a doctor is for him like unto a dagger. ${ }^{82}$

\footnotetext{
${ }^{76}$ E.g. I. Kennedy, 'Malpractice Litigation Crisis? What Crisis?' in P. Byrne (ed.), Medicine in Contemporary Society (London: King's Fund, 1987), 52-63; C. Ham, R. Dingwall, P. Fenn, and D. Harris, Medical Negligence: Compensation and Accountability (London: King's Fund Institute, 1988). 77 (2001) 9 Med L Rev 1.

${ }^{78}$ See J. Montgomery, ‘Time for a Paradigm Shift? Medical Law in Transition' (2000) 53 Current Legal Problems 354-408, 374-378 and J. Montgomery, Health Care Law 172-177 for discussion.

${ }^{79}$ S.McLean, 'Negligence - A dagger at the doctor's back? In Justice, Lord Denning and the Constitution P. Robson \& P. Watchman (eds) (1981)

${ }^{80}$ Whitehouse v Jordan [1980] 1 All ER 650, 658 (CA). The House of Lords toned this down by saying that such an error would not 'necessarily' be negligent.

${ }^{81}$ Hucks v Cole (1960) [1994] 4 Med LR 393

${ }^{82}$ Hatcher $v$ Black (1954) Times 2 July. See also Denning, The Discipline of Law (London, Butterworths 1979) 242-244.
} 
A more sophisticated approach to the value of non-intervention that demonstrates the assumption that non-intervention is a mechanism for ensuring that doctors are free to practise good medical ethics can be seen in the contribution of Lord Donaldson. He regards the legal purpose of consent as narrow, providing the doctor with a defence against being sued, but does so in the context of an appreciation of a wider 'clinical' function of consent that serves to build faith in and co-operation with the treatment. ${ }^{83}$ He has championed a legal model of partnership between patients and professionals, albeit one in which doctors are more equal than others: ${ }^{84}$

No one can dictate the treatment to be given to any child, neither court, parents nor doctors... The doctors can recommend treatment $\mathrm{A}$ in preference to treatment $\mathrm{B}$. They can also refuse to adopt treatment $\mathrm{C}$ on the grounds that it is medically contra-indicated or for some other reason is a treatment which they could not conscientiously administer. The court or parents for their part can refuse to consent to treatment A or B or both, but cannot insist on treatment $\mathrm{C}$. The inevitable and desirable result is that choice of treatment is in some measure a joint decision of the doctors and the court or parents. ${ }^{85}$

Lord Donaldson has been responsible for creating a framework for dealing with adolescent refusal of treatment, which I and others have found highly unsatisfactory. ${ }^{86}$ It permits doctors to rely on parental consent even in the face of a competent young person rejecting the treatment in question. Defending this position against criticism, he has argued that the saving grace is the context of medical ethics in which the paucity of legal rights is placed. Challenged with the observation that his proposals would permit abortion to be imposed upon a young woman who wanted to keep her child, he countered with the fact that he was confident that medical ethics would not permit it. ${ }^{87}$ The alternative view would, he suggested, place doctors in the 'intolerable' position that that they might be sued or prosecuted if they made an incorrect legal judgment as to who to go to for consent. ${ }^{88} \mathrm{He}$ was satisfied that he had established a framework that ensured that the 'doctor will be presented with a professional and ethical but not a legal problem. ${ }^{89}$

This assumption that the courts should reinforce medical decision-making rather than supplant it can be seen in the way in which the judges have handled the jurisdiction to make decisions in the best interests of patients. This has, so far, even survived the implementation of the Human Rights Act 1998. Faced with early challenges to the way in which the law has enabled fundamental decisions on matters of life and death to be determined by doctors' judgment, the courts have minimised the impact the rights-talk. Elizabeth Butler-Sloss, President of the Family division, has held that the logic of the Bland decision survives the introduction of an enforceable right to life. Thus, it remains the case that where a responsible body of professional opinion

\footnotetext{
${ }^{83} \operatorname{Re} W$ [1992] 4 All ER 627, 633.

${ }^{84}$ For the inequality of this partnership, see J. Montgomery, Health Care Law 434-437.

${ }^{85} \operatorname{Re} J$ [1991] 3 All ER 930, 934.

${ }^{86}$ See P. Alderson \& J. Montgomery, Health Care Choices: Making decisions with children (London, Institute for Public Policy Research 1996).

${ }^{87}$ Re W (1992) 9 BMLR 22, 31. See also Balcombe LJ at 41. For a challenge to this assumption, see J. Miola 'Medical law and medical ethics - complementary or corrosive?' (2004) 6 Medical Law International 251-274.

${ }^{88} \operatorname{Re} R$ [1991] 4 All ER 177, 185.

${ }^{89}$ Ibid.
} 
believes that it is not in a patient's interests to continue active treatment, it can be withdrawn. She even went so far as to argue that a responsible decision by a medical team not to provide treatment could never constitute a 'deprivation' of life within article $2 .^{90}$

This tension between the traditional norms of the 'rule of law' under which health professionals should be subject to regulation through the courts like all others and the implicit complicity between judges and doctors is best exposed through the ambiguity of the inherent jurisdiction of the court to adjudicate on the 'best interests' of incapacitated patients. In principle, this jurisdiction is exercised by the issuing of a declaration of the legal consequences of proposed or past actions. This has been used in leading House of Lords cases over the sterilisation of women with learning disabilities and the decision whether to continue life sustaining treatment for Tony Bland, the young man left in a permanent vegetative state following the Hillsborough Stadium disaster. ${ }^{91}$

Although the cases now tend to emphasise the importance of the courts considering the interests of patients rather than merely accepting medical opinion, it is hard to find evidence of them departing from professional proposals. Far from subordinating health care practice to legal control, the courts tend to see themselves as reinforcing professional ethics. ${ }^{92}$ They have been resistant to the development of hard rules, the sole exception concerning the right of competent adults to refuse treatment. ${ }^{93}$ This general approach can be characterised by the assumption that judges and health professionals have complementary roles in a single integrated system for ensuring that health care is governed by sound moral principles. While this can be portrayed as an abdication of the responsibility of law to regulate health care, it seems more accurate to describe it as the product of approach taken to judging.

There are, however, some signs that this approach is changing with a newer and less deferential cadre of judges. ${ }^{94}$ In particular, it is worth watching for the work of Munby J. In many of the cases in which the courts have refused to set ethical guidelines and standards, James Munby (then QC) represented the Official Solicitor, acting to protect the interests of incapacitated patients. In one case in 1990 he invited the Court of Appeal to establish guidance on what type of life should be regarded as so intolerable as to justify allowing a child to die. After a strong sanctity of life principle was rejected he suggested alternative tests of whether the child's life was certain to be 'bound to be so full of pain and suffering,' 'intolerable' to the child and so 'demonstrably awful' that the child 'must be condemned to die. ${ }^{95}$ The Court of Appeal chose to maintain the more general test of 'best interests' without refinement - an illustration of the resistance to rules.

Now that he is on the bench, Munby $\mathbf{J}$ is pioneering a much more legalistic approach to medical law cases. While most judges have been prepared to use the common sense

\footnotetext{
${ }^{90}$ NHS Trust $v$ M; NHS Trust $v$ H [2001] 2 FLR 367.

${ }^{91}$ Airedale NHS Trust v. Bland [1993] 1 All ER 821, F v. W. Berkshire HA [1989] 2 All ER 545.

${ }^{92}$ J. Montgomery, Health Care Law ch 18, J. Montgomery, 'Time for a Paradigm Shift? Medical Law in Transition' (2000) 53 Current Legal Problems 354-408, 402-405.

${ }^{93} \operatorname{Re} B$ (adult refusal of treatment) [2002] 2 All ER 449.

${ }^{94}$ This can be seen in the emergence of closer scrutiny of health care practice in clinical negligence litigation, although the picture is not uniform, see Health Care Law 172-177.

${ }^{95}$ Re $J$ [1990] 3 All ER 930.
} 
of the 'best interests' label to reduce the need to consider precedents and distinctions, Munby J's judgments are replete with citations and legal argument. In his hands, health care law is becoming more like law and less like an extension of professional ethics. In $R$ (Smeaton) $v$ Secretary of State for Health he presented a masterful and erudite review of case law over one hundred and fifty years, Nineteenth Century medical literature and academic literature in a judgment that ran to three hundred and ninety eight paragraphs. ${ }^{96}$ The issue in the case was whether the morning after pill could be used without the Abortion Act procedures of medical inquiry into specific legal grounds and a second opinion. Two previous judges had felt able to resolve the issue by reference to the common use of language and current medical practice. ${ }^{97} \mathrm{It}$ would have been open to Munby $\mathrm{J}$ to have elected to follow the earlier decision. ${ }^{98}$ Instead, he regarded it as important to resolve the issue by reference to full legal argument including a detailed consideration of the relevant techniques of statutory interpretation.

It is also becoming apparent that Munby $\mathrm{J}$ is less inclined than other judges to express empathy with health professionals and more concerned to treat them like any other citizens subject to the law. This has already been shown in relation to the Watts decision. It can also be seen in his greater reference to human rights law and his concern to use it to move the law in the direction he regards as desirable. ${ }^{99}$ The most important illustration of this to date can be found in Munby J's decision in $R$ (Burke) $v$ $G M C .{ }^{100}$ In that case, he upheld Mr Burke's challenge to the guidance issued by the GMC on withholding life sustaining treatment on the basis that it failed to give due regard to his human rights. In the judge's view, there were a number of failings. First, the guidance emphasised the right of competent patients to refuse treatment, and failed to give due regard to the right to require it. Second, it gave insufficient acknowledgement to the duty of a doctor, who was unwilling to provide the treatment that a patient wanted, to continue that treatment until a doctor was found who would accede to the patient's wishes. Third, it failed sufficiently to acknowledge the heavy presumption in favour of life sustaining treatment and to recognise that the touchstone of best interests was intolerability. Fourth it failed to set out the legal requirement to obtain prior judicial sanction for the withdrawal of artificial nutrition and hydration in a number of circumstances, which the judgment spelt out.

Some of these findings are more controversial than others. The criticism that there was insufficient regard to the right to require treatment, needs to be considered against the fact the previously English courts have declined to accept any such legal right to a specific treatment. ${ }^{101}$ Munby $\mathrm{J}$ seems to be working to carve one out. The second criticism is arguably a development of comments by Butler-Sloss P in Ms B vNHS Hospital Trust ${ }^{102}$ but was taken much further by Munby J, who also indicated that he

\footnotetext{
${ }^{96}$ [2002] 2 FCR 193.

${ }^{97} R v$ Price [1969] 1 QB 541, $R$ v Dhingra (1991, unreported), Birmingham CC.

${ }^{98}$ [2002] 2 FCR 193, para 253.

${ }^{99}$ E.g. the very interesting suggestions that human rights law might lead to a reassertion of adolescents' autonomy rights in disputes with their parents in Re Roddy; Torbay BC v NGN [2003] EWHC 2927.

${ }^{100}$ [2004] EWHC 1879 (Admin). As would be expected from Munby J, the judgment was brilliantly and densely argued at significant length -224 paragraphs.

${ }^{101}$ Munby J himself recognised this in R (Watts) v Bedford PCT [2003] EWHC 2228 (Admin) at Para. 43), discussed above. For further discussion of rights to treatment under the NHS, see J. Montgomery, Health Care Law chapter 3.

102 [2002] EWHC 429 (Fam).
} 
thought there were reasons to think that the traditional reluctance of the courts to compel doctors to treat against their clinical judgment might need to change in the light of the Human Rights Act $1998 .{ }^{103}$ If this view were to prevail, the relationship between the courts and doctors would change significantly. The courts would take onto themselves the responsibility to determine what treatment should be given and the right to compel doctors to accept their rulings even when they regard them as incompatible with their professional responsibilities. This would move beyond the complementary judicial and medical roles that the integrated approach to law and ethics into a more confrontational environment.

The third criticism, in relation to the sanctity of life principle and best interests, is particularly important and interesting for the fact that it saw Munby $\mathbf{J}$ championing an approach that he had put unsuccessfully before the Court of Appeal in $R e J$ as counsel in that case. ${ }^{104}$ If there is to be a redefinition of the best interests test in terms of intolerability, then this can be seen as a shift away from a broad approach that has been used by judges to justify accepting professional opinion towards a more legalistic approach that seeks to develop precise tests that health professionals are then expected to apply. In addition to the past rejection of the 'intolerability' test, there would seem to be divergent views on the current Family Division bench on its usefulness. In Portsmouth NHS Trust $v$ Wyatt Hedley J rejected the idea that such a gloss on the best interests test, or a supplementary one to be added to it, was helpful. He noted the earlier rejection of Munby's approach and declined to follow it. ${ }^{105}$ The Court of Appeal has so far upheld the traditional approach, supporting Hedley J's analysis in Wyatt and criticising that of Munby $\mathrm{J}$ in Burke. ${ }^{106}$ It remains to be seen whether Munby $\mathbf{J}$ should be seen as the pioneer of a new model of judging in health care cases, or whether this activity is an isolated diversion and the traditional approach will be continued.

The importance of these issues is high. The established non-interventionist stance is based on a deference to doctors, a belief that their practice enshrines moral values and the aspiration to construct a legal relationship between patients and health professionals that enables that morality to flourish. While deference is now hard to justify, the integrated model of law and professional activity working together to secure a common end of moral practice can be seen as a deliberate project to promote moral values. The new model judge, exemplified by Munby J, approaches things very differently. He rejects deference to the health professions, sees health care as equivalent to other (commercial) enterprises and therefore to be regulated from outside without any trust in industry values and without any special rules for health care. This constructs the position of the patient as consumer dictating what should happen, with little scope for moral independence of health professionals. Such a construction is essentially value neutral and once more serves to marginalize the moral content of medical law. It can be seen that this new approach to judging health care practice is consistent with other developments that serve to 'demoralise' the enterprise of medical or health care law.

\footnotetext{
${ }^{103}$ Burke at Paras. [180]-[194].

${ }^{104}$ [1991] Fam 33. See the text above at footnote 93.

105 [2004] EWHC 2247 (Fam).

${ }^{106}$ Wyatt v Portsmouth Hospital NHS Trust [2005] EWCA Civ 1181, para 62; R (Burke) v GMC [2005] EWCA Civ 1003, para 63.
} 


\section{The road ahead}

We now need to turn to the implications of this transformation for the future shape of what I call Health Care Law. Twenty years ago Ian Kennedy gently bemoaned the emergence of real law in the field (which he called medical law) suggesting that it sucked the life out of it.

Medical law used to be fun. All you had to do was read a lot of strange American cases, the odd Commonwealth decision, and maybe some English nineteenth century cases on crime then you could reflect that none of these was relevant and get on with the fun of inventing answers. Suddenly, in the last few years, the courts have got into the act. Cases have come rattling along. Medical law is beginning to get a corpus of law. Medical lawyers are having to do homework. ${ }^{107}$

The great advantage of the absence of legal precedent was that it was possible to go directly to the substance of the issues. Ian and his colleagues at Kings College London pioneered an approach to medical law that was sustained by a commitment to ethical values. On his analysis, the key themes that gave the subject its integrity and coherence were fundamental ethical principles:

which permeate all the problems which arise in medical law: respect for autonomy, consent, truth-telling, confidentiality, respect for persons, respect for dignity, and respect for justice. ${ }^{108}$

These principles were derived neither from legal authorities nor from professional practice, but from the emerging discipline of bioethics. I have long been critical of this approach for its failure to explain how medical law has really worked. My assessment of the material was that it was shaped far more by inter-professional politics and the assumptions made by the judiciary about the nature of medicine than this analysis allowed. These factors, I have argued, are more successful as an account of the actual practice of lawmakers in parliament and in the courts than the legal conceptualisation based on a consumerist separation of clinical and ethical issues.

My more mature reflections, as I have tried to explain, recognise that this was only a partial understanding of what was going on - medical law seen through a glass darkly as St Paul might have put it. The development of the law was not driven by such ethical principles, but it was consciously formed in such a way as to enable them to flourish. Its attractiveness was that it enabled health care professionals to work towards a high standard of ethics. This gave it a normative strength, which I had initially thought to be absent in the mere reinforcement of professional monopoly power. ${ }^{109}$ Its weakness lay in its inability to ensure that this happened. ${ }^{110}$ As I

\footnotetext{
${ }^{107}$ I. Kennedy, 'The Patient on the Clapham Omnibus' originally published at (1984) 47 MLR 454 and reprinted in I. Kennedy, Treat Me Right (Oxford: Oxford University Press 1988).

${ }^{108}$ A. Grubb, Medical Law (London: Butterworths, $3^{\text {rd }}$ ed. 2000) 3. Essentially the same quotation appears in each of the earlier editions, co-written by Ian Kennedy and Andrew Grubb.

${ }^{109}$ J. Montgomery, 'Medicine, Accountability and Professionalism' (1989) 16 JLS 319-339.
} 
suggested in 1989 and Lord Woolf argued in 2001 this approach worked only so long as levels of trust in health professionals were high.

Unfortunately, a series of scandals have served to undermine that trust; paediatric services at the Bristol Royal Infirmary 1984-1995, the Alder Hey inquiry into retention of children's organs, the murderous GP Harold Shipman. While each of these actually raises different types of problems, the cumulative effect has been to shatter the illusion that the regulation of health care does not require the same legal scrutiny as other spheres of activity. The difference between health care and other enterprises no longer seems so large either to the public or the judiciary.

There are two main roads down which this might take us. I have traced the first as being one that suppresses the moral nature of medicine and opens up health care law to general legal and market disciplines. Margaret Brazier and Nicola Glover have argued that medical law is migrating from a basis in family law, tort and jurisprudence to being founded within consumer and public law. ${ }^{111}$ They go on to ask whether, on this basis, medical law is really a subject at all. When asked that, I have usually answered that the concepts seem similar to those used more generally, but in their application to health services, they work differently.

Even the Bolam test does not exclude, as a matter of law, judicial standard setting for non-medical professionals. But for medicine, at least until recently, it has been sufficient to demonstrate that common practice has been followed. The coherence of health care law seemed to lie in its consistent trust in doctors and resistance to rule making. It was concerned with establishing procedures and providing reassurance of professional good faith rather than telling doctors what to do. The developments mapped out earlier in this piece show that these concerns are changing. In the emerging judicial approach, it is hard to see how the claim to a discrete subject area can be defended. Ian Kennedy's claim to coherence through pervasive ethical principles is even more vulnerable in this context than it was under the more integrated approach. For, as Aldous Huxley portrayed there is no place for ethics in a consumerist hedonistic Brave New World. It is all a matter of choice rather than morality. The lawyer's general tool kit will suffice with no special amendments. The development of the law without the special trust in doctors has resulted in amorality not more morality.

There would seem to be two main strategies for retrieving health care law from this demoralising amoral world. The first would be a strategy of resistance. This would need to take the form of making limitations on choice in the name of morality legitimate. The European Court of Human Rights offered some possibility of this in its decision in the Pretty case. The House of Lords had sought to exclude rights analysis from its consideration, holding that the ethical issues at stake should be considered directly, not prejudged by the definitions set out in the European Convention on Human Rights. ${ }^{112}$ The European Court of Human Rights found a role

\footnotetext{
${ }^{110}$ A point brought out strongly in J. Miola 'Medical law and medical ethics - complementary of corrosive?' (2004) 6 Medical Law International 251-274.

${ }^{111}$ M. Brazier \& N. Glover, 'Does Medical Law have a Future' in D. Hayton (ed) Law's Futures (Oxford: Hart Publishing 2000)

${ }^{112} R$ (Pretty) v DPP [2002] 1 All ER 1.
} 
for a right to autonomy, based on an important extension of article $8,{ }^{113}$ possibly the first foundation for a specific legal right to autonomy in our law. However, the Court also found that this right to autonomy was limited by the rights of others. In this case the rights of those who might be vulnerable to exploitation if the existing prohibitions on euthanasia were lifted. They accepted this without any evidence being adduced that such a risk actually existed.

This approach seeks legitimacy in the law of human rights. It has the merit that it can proceed by interpreting existing documents whose wording, if not its meaning, has been established. Further, human rights can be said to have foundational status, through international agreement, and build the enforcement of the morality that they enshrine on the basis of this form of prior consent. It has the disadvantages that is by nature legalistic, the dangers of which have already been illustrated, that the human rights documents in question have not been drafted to deal with issues in the medical context, and that scrutiny rapidly reveals that deep-rooted moral disputes, such as the proper approach to the human embryo, are barely hidden beneath the surface of the law. Yet, as we have already seen the legalistic nature of the discourse by which these debates are resolved makes addressing those deeper issues problematic.

Once health care law is something that constrains consumer choice, it becomes necessary to show why society is justified in preventing people behaving as they wish. Within the NHS this can be partly justified by the fact that receiving health care is supported by taxpayers' money and therefore does not only concern individuals. Yet in the marketplace this type of claim cannot be made, as the Blood case demonstrates. Reconceptualising health care as solely a market good pushes us, as Bobbitt suggested, to abandon the claim that we can prevent people doing things merely because they are immoral.

An alternative strategy would be built around reclaiming the moral basis of health care practice and restoring trust in medicine and the other health professions. This involves working with the professional bodies, both statutory and collegiate, such as the Royal Colleges and the BMA. The General Medical Council in particular has pursued a conscious policy of rebranding medicine in order to restore trust and retain self-regulation. ${ }^{114}$ In many ways they are catching up with the other health professions who have previously used strategies of professionalisation in similar ways. ${ }^{115}$ The BMA has been one of the most prolific producers of ethical guidance in the health care system. This is an approach that seeks to restore legitimacy to the assumptions on which the integrated approach to health care law and ethics is based.

Health care lawyers can and have been playing an important role in this process. Many working parties and committees include legal academics. Sir Ian Kennedy has played a crucial role in shaping the current culture of the NHS through his report into Paediatric Surgery in Bristol and as Chair of the Healthcare Commission. Professor Margaret Brazier has chaired the Retained Organ Commission handling some of the consequences of the failure to secure parental consent to post-mortems at the Alder

\footnotetext{
${ }^{113}$ Pretty v UK [2002] 2 FCR 97.

${ }^{114}$ See J. Montgomery, 'Time for a Paradigm Shift? Medical Law in Transition' (2000) 53 Current Legal Problems 354-408.

${ }^{115}$ J. Montgomery, 'Professional regulation: a gendered phenomenon? In S. Sheldon \& M. Thomson (eds) Feminist Perspectives in Health Care Law (London: Cavendish 1998).
} 
Hey Hospital in Liverpool and elsewhere. Professor Alexander McCall Smith is vicechair of the Human Genetics Commission. Following the decision in the Blood case, Professor Sheila Maclean reviewed the law for the Department of Health. For those of us who are driven by wanting to make a positive contribution to health services, this route rather than the confrontational one is the more attractive.

So how successful has the law been, and how successful can it be in maintaining a moral basis for health care practice? I suggested in a lecture at UCL in 2000 that the attempt to set and police moral standards for medicine from outside through the law had failed to demonstrate much impact, due mostly to lack of sympathy with this project from the judges. ${ }^{116}$ I am not much encouraged by the new found enthusiasm for intervention because it seems to me to have had the result of excluding moral concerns rather than promoting them.

I have suggested that in the integrative mode, while the law did little to alter the moral values that underpinned practice, it did create a legal context in which that professional morality could flourish. If the disturbing trends that I have identified continue, there are strong reasons to think that the engagement of law with medicine is proving demoralising in both of the senses that I outlined at the beginning of this lecture. It is making debate about the morality of health care practice more difficult and undermining the morale of health professionals. The question now is how those pitfalls can be evaded. I believe that it can only be through a partnership between law and medicine constructed to maintain a moral basis for health care practice.

This can be seen in Rowan Williams' terms as moving on from a pre-modern period in which law merely sanctioned medical power, overcoming the rivalry of the modern period, but avoiding the pitfall of a value free public sphere where medicine is merely another commodity in the market-state. It does so by reasserting the fundamental connection between medicine and morality through the creation of an intermediate professional community, neither purely of the state, nor merely individual economic actors. For Williams this was the role of religious faiths, for us it is the role of collegiate health care professions.

I hope, therefore, that I have mapped out some of the roads that health care has been following and hopes to travel down. I have described some of the winds of change that drive us along, and some of the sources of the energy that sustains good practice. I have tried to show that there can still be a place for ethics in health care practice, although we will have to fight for it, and that morale amongst professionals need not be low. I trust that the future for health services and health care law will be long and distinguished.

\footnotetext{
${ }^{116}$ J. Montgomery, 'Time for a Paradigm Shift? Medical Law in Transition' (2000) 53 Current Legal Problems 354-408.
} 